\title{
SMART HORNBEAM STANDS (CARPINUS BETULUS L.) FROM THE WEST PLAIN
}

\author{
Dincă Lucian $^{1 *}$, Breabăn Iuliana Gabriela ${ }^{2}$ \\ 1 "Marin Drăcea" National Institute for Research and Development in Forestry, 13 Cloşca \\ Street, Braşov-500040, Romania. \\ 2 "Alexandru Ioan Cuza" University of Iasi, e-mail: iulianab2001@gmail.com \\ *Corresponding author: dinka.lucian@gmail.com
}

Keywords: smart forests, hornbeam, altitude, age, exposition.

\begin{abstract}
Hornbeam is a forest tree species widespread in our country's plain and hill areas. Hornbeam forests can also be found in the West Plain and can be classified as smart forests. This concept, used during the last decade in worldwide silviculture, involves the existence of forests with an exceptional ecologic purpose. The present article intends to establish a set of clear and easy to identify and catalogue criteria that can be used to recognize smart hornbeam forests from the West Plain together with their characteristics. In order to achieve this, 14 site and stand characteristics were established, each with five evaluation classes.

Smart hornbeam stands from the West Plain are distributed especially in Lunca Timisului, Oradea and Timisoara forest districts, at altitudes of 90-100 meters, on preluvisol and eutric cambisol. In addition, they are also present in forest plain station and in meadows, being characterised by relatively even-aged and relatively uneven-aged structures, ages between 60-70 years and by conservation forests and seed reservations production subunits.
\end{abstract}

\section{INTRODUCTION}

The West Plain is composed of three layers: high plain (over $100 \mathrm{~m}$ ), horizontal plain (with sand accumulations) and low plain (in which rivers have a swamp tendency). The forest vegetation is composed of broad-leaved stands, including numerous hornbeam elements. The main soils are chernozem, phaeozem and preluvisol (Crișan et al., 2017; Dincă et al., 2019a).

Six associations that contain hornbeam were identified in the Czech Republic (Knollova, 2004). In Slovakia, the entire hornbeam leaf canopy (over storey and under storey canopy) is a large sink of $\mathrm{CO}_{2}$ in good forest light conditions (Elias et al., 1989). In Poland, the decomposition rate of plant litter fall coefficients were of 1.06 for hornbeam leaves (Dziadowiec, 1987). In Sweden, soil acidity leads to a large extent of field-layer vegetation floristic composition in oak/hornbeam forests (Tyler, 1989). 
Forestry is the only sector of the economy that acts as a net sink for $\mathrm{CO}_{2}$. Terrestrial ecosystems in Europe already sequester $7 \%$ to $12 \%$ of the anthropogenic $\mathrm{CO}_{2}$ emissions, even though the potential of forests is not fully utilized (Janssens et al., 2003; Luyssaert et al., 2010). Climate-smart forestry includes reducing emissions of greenhouse gases, building resilience in existing forests, and increases in forest productivity. Climate-smart forestry seeks synergies with other policies such as the enhancement of biodiversity, the provision of forest ecosystem services, and the establishment of a strong bio-economy (Jandl et al., 2018). Climate-smart forestry is sustainable adaptive forest management and governance to protect and enhance the potential of forests to adapt to, and mitigate climate change; it should enable both forests and society to transform, adapt to and mitigate climate-induced changes (Bowditch et al., 2020).

The purpose of this article is to establish the smart hornbeam forests from the West Plain, similar with the stands from the Southern Carpathians that are composed of alder (Blaga et al., 2019) or Norway spruce (Dincă et al., 2019b).

\section{MATERIALS AND METHODS}

The present article uses data from forest management plans realized during 1995-2008 for all national forests located in the West Plain (11 forest districts have stands that contain hornbeam in their composition). All hornbeam stand elements were analysed for species older than 50 years ( 3155 elements of hornbeam stands). As such, 14 parameters specific tolus the stand or station were taken into consideration (table 1). Each parameter was graded from 1 to 5 , based on the specie's ecological and silviculture requests, as follows: $1=$ very low; $2=$ low; $3=$ average; $4=$ high; $5=$ very high. A total grade was obtained by adding all values that correspond to a stand and it was used to order and classify hornbeam stands from the West Plain.

Table 1. Grades assigned on the stand's characteristic

\begin{tabular}{|c|c|c|c|c|c|c|}
\hline \multirow{2}{*}{$\begin{array}{l}\mathrm{Nr} \\
\mathrm{crt}\end{array}$} & \multirow[t]{2}{*}{ Characteristic } & \multicolumn{5}{|c|}{ Grade } \\
\hline & & 1 & 2 & 3 & 4 & 5 \\
\hline 1 & Pruning & 0.3 & 0.4 & 0.5 & 0.7 & 0.6 \\
\hline 2 & Vitality & 5 & 4 & 3 & 2 & 1 \\
\hline 3 & $\begin{array}{l}\text { Average diameter } \\
(\mathrm{cm})^{*}\end{array}$ & $10-16$ & $18-20$ & 22 & 24 & $26-90$ \\
\hline 4 & $\begin{array}{l}\text { Average high } \\
(\mathrm{m})^{*}\end{array}$ & $9-16$ & $17-18$ & 19 & 20 & $21-42$ \\
\hline 5 & Production class & 5 & 4 & 3 & 2 & 1 \\
\hline 6 & $\begin{array}{l}\text { Current growth } \\
\left(\mathrm{m}^{3} / \text { year/ha)* }\right.\end{array}$ & $0.1-0.4$ & $0.5-0.7$ & $0.8-1.3$ & $1.4-2.7$ & $2.8-7.2$ \\
\hline 7 & Structure & & 1 & 2 & 3 & 4 \\
\hline 8 & Consistency & $0.3-0.4$ & $0.5 ; 1.0$ & $0.6-0.9$ & 0.7 & 0.8 \\
\hline
\end{tabular}




\begin{tabular}{|c|c|c|c|c|c|c|}
\hline 9 & SUP & $\mathrm{O} ; \mathrm{C}$ & $\mathrm{A} ; \mathrm{Q}$ & $\mathrm{V}$ & $\mathrm{K}$ & $\mathrm{M}$ \\
\hline 10 & $\begin{array}{l}\text { Functional group } \\
+ \\
\text { Functional } \\
\text { category }\end{array}$ & $2,1 \mathrm{C}$ & $2,1 \mathrm{~B}$ & $\begin{array}{c}1,1 \mathrm{~B} ; \underset{1,1 \mathrm{C} ; 1,2 \mathrm{I} ;}{1,4 \mathrm{~J}} \\
\text {; }\end{array}$ & $\begin{array}{c}1,2 \mathrm{~A} ; 1,2 \mathrm{~B} \\
\quad ; 1,2 \mathrm{~L} ; \\
1,4 \mathrm{~B}\end{array}$ & $\begin{array}{l}1,3 \mathrm{C} \\
1,5 \mathrm{H}\end{array}$ \\
\hline 11 & Litter & 1 & 2 & 3 & 4 & 5 \\
\hline 12 & Flora & 42 & $44 ; 45 ; 67$ & $41 ; 63 ; 66$ & $51 ; 62$ & $\begin{array}{c}61 ; 71 ; \\
81\end{array}$ \\
\hline 13 & Soil type & $\begin{array}{l}2405 ; \\
2410\end{array}$ & 2407 & 2401 & $\begin{array}{l}2101 ; \\
2201 ; \\
2212\end{array}$ & $\begin{array}{l}2102 \\
3101\end{array}$ \\
\hline 14 & Station type & 6122 & $6131 ; 6142$ & $\begin{array}{c}5142 ; 5152 ; \\
5242 ; 6132 ; \\
6252\end{array}$ & $\begin{array}{l}5132 ; \\
5153 ; \\
6143\end{array}$ & $\begin{array}{l}6253 \\
7333\end{array}$ \\
\hline
\end{tabular}

*The entire value range was divided for these characteristics in 5 categories, $1=$ the lowest (ex: average diameter between 10-16 cm), $5=$ the highest (ex: current growth larger than $2.8 \mathrm{~m}^{3} / \mathrm{year} / \mathrm{ha}$ ) and grades were given for these categories. The category division was realized to respect the analysed biometric characteristics but also to ensure a balanced division as value numbers for each category.

The meaning of terms used in Table number 1 is rendered below:

Vitality: $1=$ very vigorous; $2=$ vigorous; $3=$ normal; $4=$ =weak; $5=$ very weak.

Structure: $1=$ even-aged stands; $2=$ relatively even-aged stands; $3=$ relatively uneven-aged stands; $4=$ uneven-aged stands.

Production/protection subunits (SUP) (excerpt): $A=$ regular forest, common assortments: wood for timber, constructions, celluloses; $\mathrm{C}=$ Conversion; $\mathrm{K}=$ Seed reservations; $\mathrm{M}=$ Forests under the extreme conservation regime; $\mathrm{O}=$ Fields that will be removed from the forest fund; $\mathrm{V}=$ Forests with recreation functions through hunting in which forest regeneration cuttings are allowed.

Functional group (GF) and functional category (FCT) (excerpt): 1,2A= Forests located on cliffs, debris, on fields with depth erosion, on fields with a slope higher than 35 degrees and on flysch, sand or gravel with a slope higher than 30 degrees; 1,2L= Forests located on fields with lithological substratum very vulnerable to erosion and landslide; $1,3 \mathrm{C}=$ Oak forests from field areas under the conservation regime; $1,4 \mathrm{~B}=$ Forests from around counties, cities and villages as well as forests located in their construction area; $1,4 \mathrm{~J}=$ Forests with an exceptional game interest; $1,5 \mathrm{H}=$ Forests established as reservations for the production of forest seeds and the conservation of the forest genofund; $2,1 \mathrm{~B}=$ Forests destined to mainly produce voluminous trees of superior quality for timber.

Litter: $1=$ missing litter; $2=$ slim interrupted litter; $3=$ slim continous litter; $4=$ normal continuous litter; $5=$ voluminous continous litter.

Flora: $41=$ Asperula-Asarum; 42= Carex pilosa $; 44=$ Festuca altissima $; 45=$ Luzula albida $; 51=$ Asarum-Brachypodium; $61=$ Asarum-Stellaria $; 66=$ Festuca heterophylla $; 67=$ Poa pratensis-Carex caryophyllae $; 71=$ Erachypodium-Geum-Pulmonaria $; 81=$ Arum-Pulmonaria.

Soil type: $2101=$ rodic preluvisol; $2102=$ mollic rodic preluvisol; $2201=$ preluvisol; $2212=$ mollic marnic preluvisol; 2401= luvisol; 2405= lithic luvisol; 2407= stagnic luvisol; $2410=$ planic stagnic luvisol; 3101= eutric cambisol.

Station type: $5132=\mathrm{Bm}$ hill holm, preluvisol and luvisol with mesophyte gramineae flora; $5242=$ Bm hill common beech stand, average edaphic eutric cambisol with Asperula-Asarum; 6143= Bs hill oak stands (holm stands) and hill highroads, high edaphic stagnic preluvisol with Carex pilosa; 6253= Bs hill oak stands with common beech stand of inferior limit, high edaphic eutric cambisol; 7333= Bs hill oak stands with oak, high edaphic stagnic preluvisol. 


\section{RESULTS AND DISCUSSIONS}

Taking into consideration the fact that smart forests represent up to $10 \%$ of the total forests from an area, this category contains forests with a grade higher than 54, namely 30 stands in the case of the West Plain. These numbers were obtained by the decreasing classification of the grades obtained by each stand. The following aspects were identified by analysing certain characteristics of these 30 stands (table 2):

Table 2. Characteristics of smart hornbeam forests from the West Plain

\begin{tabular}{|c|c|c|c|c|c|c|c|}
\hline $\begin{array}{c}\text { Nr } \\
\text { crt }\end{array}$ & $\begin{array}{c}\text { Forest } \\
\text { district }\end{array}$ & $\begin{array}{c}\text { Age } \\
(\text { years })\end{array}$ & $\begin{array}{c}\text { Altitude } \\
(\mathbf{m})\end{array}$ & SUP & Structure & Soil type & $\begin{array}{c}\text { Station } \\
\text { type }\end{array}$ \\
\hline 1 & Livada & 60 & 130 & $\mathrm{M}$ & 2 & 2401 & 8512 \\
\hline 2 & Lunca Timis & 130 & 100 & $\mathrm{M}$ & 3 & 2102 & 8512 \\
\hline 3 & Lunca Timis & 80 & 100 & $\mathrm{~K}$ & 3 & 2212 & 8511 \\
\hline 4 & Lunca Timis & 85 & 100 & $\mathrm{~K}$ & 1 & 2212 & 8511 \\
\hline 5 & Lunca Timis & 70 & 90 & $\mathrm{~V}$ & 2 & 2102 & 8512 \\
\hline 6 & Lunca Timis & 70 & 90 & $\mathrm{~V}$ & 3 & 2102 & 8512 \\
\hline 7 & Tinca & 80 & 110 & $\mathrm{~K}$ & 2 & 9511 & 8512 \\
\hline 8 & Savarsin & 110 & 425 & $\mathrm{~B}$ & 2 & 3101 & 5243 \\
\hline 9 & Lunca Timis & 130 & 100 & $\mathrm{~V}$ & 3 & 2102 & 8512 \\
\hline 10 & Oradea & 70 & 180 & $\mathrm{~A}$ & 2 & 3101 & 6153 \\
\hline 11 & Oradea & 70 & 170 & $\mathrm{~A}$ & 2 & 3101 & 6153 \\
\hline 12 & Lunca Timis & 75 & 100 & $\mathrm{~V}$ & 3 & 2101 & 8511 \\
\hline 13 & Lunca Timis & 75 & 100 & $\mathrm{~K}$ & 2 & 2212 & 8511 \\
\hline 14 & Lunca Timis & 80 & 100 & $\mathrm{~V}$ & 3 & 2101 & 8511 \\
\hline 15 & Lunca Timis & 90 & 100 & $\mathrm{~K}$ & 2 & 2212 & 8511 \\
\hline 16 & Timisoara & 55 & 160 & $\mathrm{~A}$ & 2 & 2201 & 7220 \\
\hline 17 & Savarsin & 60 & 350 & $\mathrm{M}$ & 2 & 2201 & 5153 \\
\hline 18 & Timisoara & 60 & 170 & $\mathrm{~A}$ & 2 & 2201 & 7430 \\
\hline 19 & Oradea & 65 & 170 & $\mathrm{M}$ & 2 & 2407 & 7333 \\
\hline 20 & Lunca Timis & 65 & 90 & $\mathrm{~V}$ & 1 & 2102 & 8512 \\
\hline 21 & Oradea & 70 & 220 & $\mathrm{~A}$ & 2 & 3101 & 6153 \\
\hline 22 & Oradea & 70 & 225 & $\mathrm{~A}$ & 2 & 3101 & 6153 \\
\hline 23 & Sacuieni & 70 & 160 & $\mathrm{~V}$ & 2 & 2101 & 8430 \\
\hline 24 & Sacuieni & 70 & 170 & $\mathrm{~V}$ & 3 & 2201 & 8430 \\
\hline 25 & Lunca Timis & 70 & 90 & $\mathrm{~V}$ & 3 & 2102 & 8512 \\
\hline 26 & Timisoara & 80 & 150 & $\mathrm{~A}$ & 1 & 2201 & 6142 \\
\hline 27 & Lunca Timis & 80 & 100 & $\mathrm{M}$ & 1 & 2212 & 8511 \\
\hline 28 & Lunca Timis & 85 & 100 & $\mathrm{~A}$ & 3 & 2102 & 8512 \\
\hline 29 & Satu Mare & 90 & 120 & $\mathrm{~K}$ & 2 & 6202 & 8336 \\
\hline 30 & Lunca Timis & 125 & 90 & $\mathrm{~V}$ & 3 & 2119 & 8512 \\
\hline
\end{tabular}

From a geographic distribution point of view, smart hornbeam forests are present especially in Lunca Timisului, Oradea and Timisoara forest districts but 
can also be found (in reduced quantities) in Sacuieni, Savarsin, Livada, Satu Mare and Tinca (fig. 1).

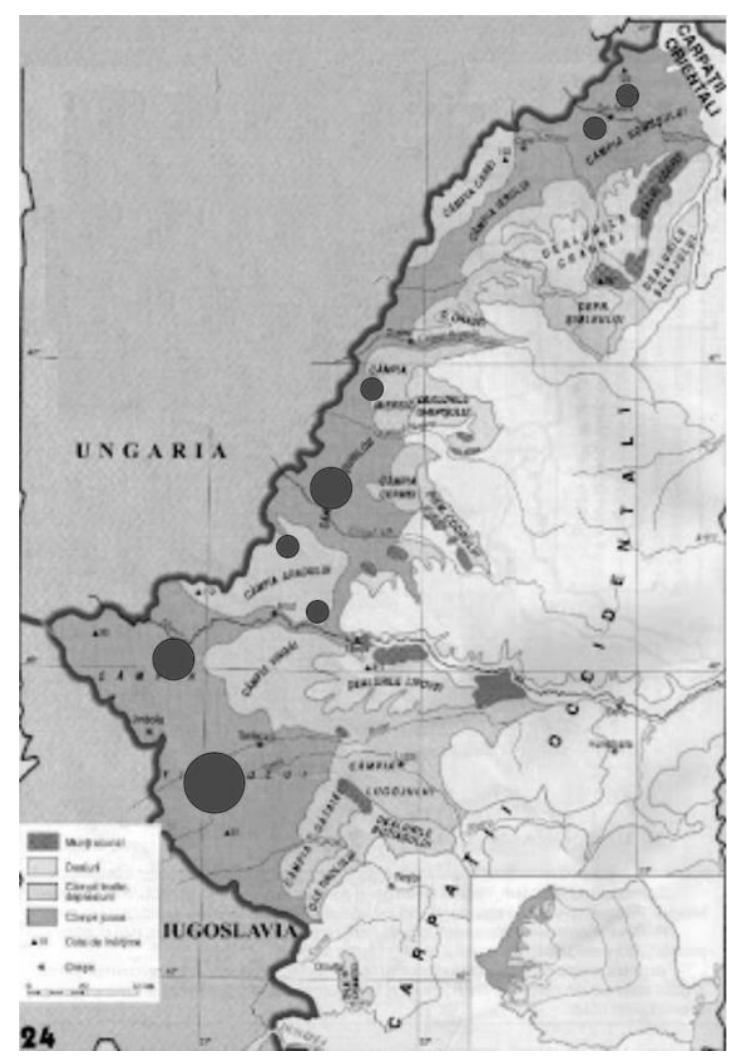

Figure 1. Distribution of smart hornbeam forests in the West Plain (http://geografiebranesti.blogspot.com main map)

The age of these smart forests is varied, ranging from 55 to 130 . This fact proves that advanced age is not necessarily a condition for the appearance of these stands. Relatively young forests (60-70 years old) record other characteristics that situate them in this superior stand category. Furthermore, it can be observed that the majority of stands range between 55-70 years (fig. 2). 


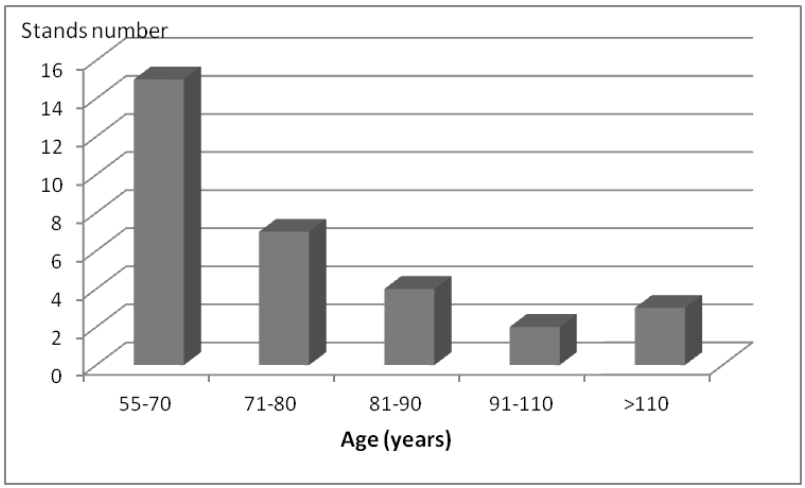

Figure 2. Distribution of smart hornbeam forests from the West Plain on ages

As an altitudinal spreading, these stands are situated between 90 and 425 meters, with preponderance for the 90-100 m altitude (fig. 3).

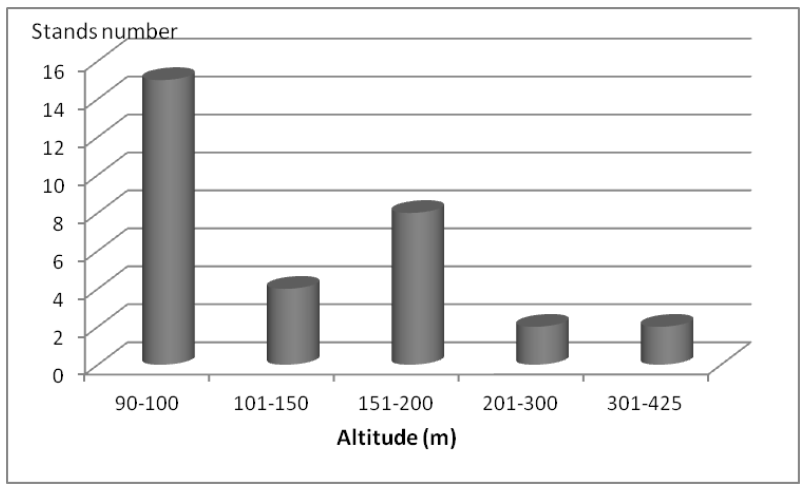

Figure 3. Distribution of smart hornbeam forests from the West Plain on altitudes

From a production/protection point of view, smart hornbeam forests from this area are relatively evenly distributed in the following categories: V - Forests with recreation functions through hunting, A - Regular forest, common assortments, $\mathrm{K}$ Seed reservations and $\mathrm{M}$ - Forests under the special conservation regime (fig. 4).

The structure of these stands is mainly 2-relatively even-aged stands and 3relatively uneven-aged stands, with the presence of 1-even-aged stands (which has recorded the lowest grade). This fact proves once again that classifying a forest as smart forest is determined by more factors.

The soil type characteristics for these stands are: 2102-mollic rodic preluvisol, 2201-preluvisol, 2212-mollic marnic preluvisol and 3101-eutric cambisol. These 
soils are favourable to the local forest vegetation (Spârchez et al., 2017; Dinca et al., 2018).

The characteristic station types are 8511- Bm meadow highroad forest plain, high edaphic stagnosol and 8512 - Bs meadow highroad forest plain, high edaphic stagnosol. Besides a good protection (Constandache et al., 2018; Dincă et al., 2019 c), these station types also ensure multiple ecosystem functions (Pleșca et al., 2019; Dincă et al., 2020; Enescu et al., 2020).

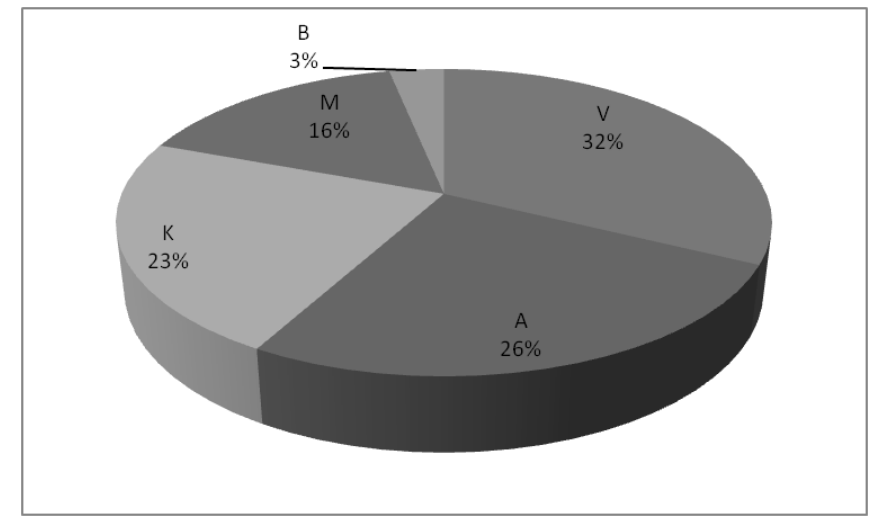

Figure 4. Distribution of smart hornbeam forests from the West Plain on production/protection subunits

\section{CONCLUSIONS}

Framing a stand in the smart forest category must take into account a sum of factors. Our study has shown that smart hornbeam forests can be established by taking into account 14 site and stand characteristics. The identification of these stands is extremely important for applying adequate silvicultural measures for their protection.

Hornbeam smart forests are present in the entire West Plain but especially in Lunca Timisului, Oradea and Timisoara forest districts. They are characterised by ages of 60-70 years, altitudes between 90-100 m, relatively even-aged and relatively uneven-aged structures and preluvisol and eutric cambisol soil types. They are situated in forest meadow highroad plain station and in production/protection subunits from the following classes: A - Regular forest, common assortments, $\mathrm{K}$ - Seed reservations and $\mathrm{M}-$ Forests under the extreme conservation regime. 


\section{References}

Bowditch, E., Santopuoli, G., Binder, F., Rio, M. D., La Porta, N., Kluvankova, T., ... \& Pretzsch, H. (2020). What is Climate-Smart Forestry? A definition from a multinational collaborative process focused on mountain regions of Europe. Ecosystem Services,

43, 101113 https://doi.org/10.1016/j.ecoser.2020.101113

Blaga, T., Dinca L., Pleșca, I. M. (2019). How can smart alder forests (Alnus glutinosa (L.) Gaertn.) from the Southern Carpathians be indentified and managed. Scientific papers series „Management, Economic Engineering in Agriculture and Rural Development", 19(4): 29-35, [link]

Constandache, C., Dinca, L., Tudose, N.C., Panaitescu, C. (2018). Protecting surface water resources through silvicultural methods. International Symposium "The Environment and the Industry", SIMI 2018, Proceedings book Section Pollution Assessment \& Management Systems, pag. 276-284, 10.21698/simi.2018.fp33

Crișan, V., Dincă, L. (2017). The predominant forest soils from Timiș Forest Administration County. JOURNAL of Horticulture, Forestry and Biotechnology, 21(3): 137-141. [link]

Dinca, L., Badea, O., Guiman, G., Braga, C., Crisan, V., Greavu, V., Murariu, G., Georgescu L. (2018). Monitoring of soil moisture in Long-Term Ecological Research (LTER) sites of Romanian Carpathians. Annals of Forest Research, 61(2): 171-188, DOI: 10.15287/afr.2018.1188

Dinca, L., Chisalita, I., Cantar, I.C. (2019). Chemical properties of forest soils from Romania's West Plain. Revista de Chimie, 70(7): 2371-2374. [link]

Dincă, L., Murariu, G., Iticescu, C., Budeanu, M., Murariu, A. (2019). Norway spruce (Picea Abies (L.) Karst.) smart forests from Southern Carpathians. International Journal of Conservation Science, 10(4): 781-790. [link]

Dincă, L., Achim, F. (2019). The management of forests situated on fields susceptible to landslides and erosion from the Southern Carpathians. Scientific papers series Management, Economic Engineering in Agriculture and Rural Development, 19(3): 183-188. [link]

Dincă, L., Timiș-Gânsac, V. (2020). The usage of non-wood forest products - Culinary and artisanal traditions in Romania. Sustainable Development Research; 2(1): 50-57, DOI: https://doi.org/10.30560/sdr.v2n1p50

Dziadowiec, H. (1987). The decomposition of plant litter fall in an oak-linden-hornbeam forest and an oak-pine mixed forest of the Białowieża National Park. Acta Societatis Botanicorum Poloniae, 56(1), 169-185, DOI: https://doi.org/10.5586/asbp.1987.019

Eliáš, P., Kratochvílová, I., Janouš, D., Marek, M., Masarovičová, E. (1989). Stand microclimate and physiological activity of tree leaves in an oak-hornbeam forest. Trees, 3(4), 227-233.

Enescu, R., Dincă, L. (2020). An assessment of forest fruits from Arad County. Annals of the University of Craiova - Agriculture, Montanology, Cadastre Series, 49(2): 107112, http://anale.agro-craiova.ro/.../874 
Jandl, R., Ledermann, T., Kindermann, G., Freudenschuss, A., Gschwantner, T., Weiss, P. (2018). Strategies for climate-smart forest management in Austria. Forests 9, 1-15, DOI: https://doi.org/10.3390/f9100592

Janssens, I.A., Freibauer, A., Ciais, P., Smith, P., Nabuurs, G.J., Folberth, G., Schlamadinger, B., Hutjes, R.W.A., Ceulemans, R., Schulze, E.D. et al. (2003). Europe's terrestrial biosphere absorbs 7 to 12\% of European anthropogenic CO2 emissions. Science, 300, 1538-1542, DOI: https://doi.org/10.1126/science.1083592

Knollová, I. (2004). Oak-hornbeam forests of the Czech Republic: geographical and ecological approaches to vegetation classification. Preslia, Praha, 76: 291-311. [link]

Luyssaert, S., Ciais, P., Piao, S.L., Schulze, E.D., Jung, M., Zaehle, S., Schelhaas, M.J., Reichstein, M., Churkina, G., Papale, D. et al. (2010). The European carbon balance. Part 3: Forests. Glob. Chang. Biol., 16, 1429-1450. ttps://doi.org/10.1111/j.1365-2486.2009.02056.x

Pleșca, I.M., Blaga, T., Dincă, L., Breabăn, I.G. (2019). Prioritizing the potential of nonwood forest products from Arad county by using the analytical hierarchy process. Present Environment and Sustainable Development, 13(2): 225-233. 10.2478/pesd2019-0038

Spârchez, G., Dincă, L., Marin, G., Dincă, M., Enescu, R.E. (2017). Variation of eutric cambisols' chemical properties based on altitudinal and geomorphological zoning. Environmental Engineering and Management Journal, 16(12), 2911-2918. [link]

Tyler, G. (1989). Interacting effects of soil acidity and canopy cover on the species composition of field-layer vegetation in oak/hornbeam forests. Forest ecology and management, 28(2), 101-114, DOI: https://doi.org/10.1016/0378-1127(89)90063-7

*** Amenajamentele silvice ale ocoalelor: Carei (2008), Chisinau Cris (2001), Livada (2001), Lugoj (1999), Lunca Timisului (2007), Oradea (2007), Radna (1995), Satu Mare (2004), Savarsin (2005), Timisoara (2007), Tinca (2008).

(C) 2020 by the authors. Licensee UAIC, Iasi, Romania. This article is an open access article distributed under the terms and conditions of the Creative Commons Attribution (CC BY-NC-ND) license (https://creativecommons.org/licenses/by-nc-nd/4.0). 